\title{
Factors Influencing Taxpayers' Voluntary Compliance Attitude with Tax System: Evidence from Gedeo Zone of Southern Ethiopia
}

\author{
Kanbiro Orkaido Deyganto \\ Accounting and Finance Department, Dilla University, Dilla, Ethiopia
}

Copyright $(\mathrm{C} 2018$ by authors, all rights reserved. Authors agree that this article remains permanently open access under the terms of the Creative Commons Attribution License 4.0 International License

\begin{abstract}
Taxpayers' voluntary compliance attitude with tax system is influenced by demographic, individual, social, institutional and economic factors. Thus, the objective of this study was to examine the factors influencing tax voluntary compliance attitude with tax system the case of Gedeo Zone. To this end, the author used mixed research approach. The target populations of the study were tax authority and taxpayers in Zone. A sample of 323 taxpayers was randomly taken from the 1,678 taxpayers in the Zone but tax officers were judgmentally selected by the researcher in order to collect sufficient and relevant information required to prepare the report of this study. Both primary and secondary data were collected. Primary data were collected through structured questionnaire and interview with officers and taxpayers representatives. The secondary data were also collected by reviewing of related published and unpublished materials. Binary logistic regression model was employed to analysis the data through Stata software application version 12.0 and SPSS version 23.0 were used to present the results of this study. Then, the result of this study showed that out of fourteen explanatory variables incorporated in the model, seven variables such as gender, age, lack of tax knowledge, simplicity of tax system, awareness on penalty, probability of being audit, and perception on tax rate were found to be key factors influencing taxpayers' voluntary compliance attitude with tax system in the study area. Whereas variables such as education level, tax authority efficiency, peer influence, occupation, income level of taxpayers, perception on government speeding, and perception on fairness and equity have no significant influence on tax voluntary compliance attitude. Finally, the findings of the study may inform policy makers about the factors influencing voluntary compliance attitude towards tax system in the Zone and supports to formulate constructive policy in order to achieve the goal of raising required tax revenue to promote the economic development of the country.
\end{abstract}

Keywords Tax System, Taxpayers' Voluntary Compliance Attitude, Binary Logit Model, Gedeo Zone

\section{Introduction}

Tax revenue is powerful resource to funding the public payments of developed, developing and underdeveloped countries in the world. But the amount of revenue to be generated by a government from taxes for its expenditure program depends on the willingness of the taxpayers to comply with tax laws of a country [20] and [21]. Moreover, in developing countries many problems like poor administration, failing to collect sufficient tax revenues, tax structures where tax horizontal and vertical equity considerations are not integrated, lack of government and economic stability [55]. Besides, degree of tax compliance in most these countries is affected by demographic, individual, social, economic and institutional factors [33] and [36]. Since each country has its own approach to managing tax compliance attitude and each has different tax laws and regulations for the factors affecting tax compliance attitude appear to vary among countries [40].

Ethiopia, like any other developing countries, faces difficulty in raising revenue to the level required for the promotion of economic growth through making different tax reforms for improving revenue generation, enhancing the efficiency of tax administration and improving equity in the tax system. To this effect, Study done by [9] on determinants of tax revenue from time series of [1992-2013] declared that the trend of tax collection in Ethiopia is inconsistent, changing upward and downward due to different individual taxpayers, institutional, demographic, social and economic related factors that influencing compliance attitude of taxpayers with taxation. 


\subsection{Statement of the Problem}

Tax income is the major source of the government to finance public expenditure. It is paid by citizens as an obligation without expecting any direct benefit in turn. Even if tax is base for the existence of the state, most taxpayers become unwilling to pay their tax obligations due to the presence of negative voluntary compliance attitude. Non-compliant taxpayers take a variety of actions to reduce their tax liability [8]. Negative tax voluntary compliance attitude is individuals' failure to comply with their tax commitment. Hence, study by [36] broadly categorized negative compliance as failing to file a tax return; underreporting of taxable income; overstating tax claims such as deductions and exemptions and failing to make timely payment of tax liability. In contrary, positive tax voluntary compliance attitude is the willingness of taxpayers to comply with tax system. To this effect, [12] stated that voluntary compliance attitude with tax laws involves true reporting of the taxable income; correct computation of the tax liabilities; timely filling of tax returns and timely payment of the amount owing as tax obligation.

Tax negative voluntary compliance attitude is burning issue in developing countries in the world especially subSharan Africa countries. None-compliance attitude reduces tax revenue generation capability to the amount planned to be collected by government and leads to budget deficit these countries. This evidenced by study [24] that argued now the governments of developing countries, particularly sub-Sharan Africa countries collect much lower proportions of their GDPs of tax revenue which is less than average is $16 \%$ even if they have high capacity to raise tax revenue to promote their economic development. Ethiopia, like any other developing countries, faces difficulty in raising tax revenue to the level required for the promotion of economic growth. Hence, according to [18] tax to GDP ratio which was collected in GTP I is $13.3 \%$ even though the government has been planned to raise $15.3 \%$ tax-to-GDP. The main reason of this low revenue collection performance is due to tax noncompliance attitude of business income tax payers' tax payers and poor tax administration [28].

Most researches conducted on tax compliance attitude issues were done in developed countries. For instance studies such as [5] in Norway, [31] in New Zealand and [43] in Spain and Turkey out tax compliance of taxpayers is influenced by factors including age, education level, ethnicity, income level, tax knowledge, probability of being audit, perception on government spending, fear of penalty, personal financial constraints and existence of referent groups in self-assessment system. When it comes to Ethiopia, there are few researches done on the same topic and related issues in country. For example, the studies conducted by [13]; [8], [55], [65] and [56] on the same issue by incorporating up to nine explanatory variables in their study and made different suggestions about tax voluntary compliance attitude of taxpayers' on different study areas in the country.

But, the current research is different from the above reviewed researches in Ethiopia by incorporating five more additional variables influencing tax voluntary compliance attitude of taxpayers' with tax system. And also unlike the previous studies, current study also employed logit model and planned to fill time gap that the studies have been conducted earlier time does not disclose the current impact that determinants of tax voluntary compliance attitude of taxpayers'. Therefore, aforementioned problems necessitate this study to be carried out and doing this research will fills the gap of methodology and other gaps mentioned above about factors influencing of tax voluntary compliance attitude from both taxpayers' and tax authority perspective in Gedeo Zone.

\subsection{Objectives of the Study}

The major objective of this study is to identify the factors influencing taxpayers, voluntary compliance attitude of taxpayers in Gedeo Zone.

In line with above general objective, the specific objectives of the study are:

1. To test whether the demographic factors such as gender, occupation, age and education level have impact on tax compliance attitude taxpayers.

2. To examine effect of individual factors such tax knowledge and awareness on penalty on compliance attitude of taxpayers.

3. To investigate the influence of social factors, peer influence, perception on fairness and equity of tax system on compliance attitude of taxpayers.

4. To see the effect of institutional factors like simplicity of tax system and organizational efficiency of tax authority on tax compliance attitude

5. To confirm the impact of economic factors such as the probability of being audit, perception on government spending and perception on tax rate on tax compliance.

6. To examine the level of tax compliance among the three categories of taxpayers in the Zone

\subsection{Research Hypotheses}

H1: Male taxpayers have negative voluntary compliance attitude than female taxpayers

H2: Elder taxpayers are more compliant than young taxpayers

H3: Education level of taxpayers is positively correlated with tax compliance attitude

H4: Tax voluntary compliance attitude is positively correlated with tax knowledge 
H5: Peer influence or referent group has negative association on voluntary compliance attitude of taxpayers

H6: Occupation of taxpayer is positively associated with compliance attitude

H7: Simplicity of tax system is positively related with tax compliance attitude.

H8: Perception on fairness and equity of tax system is positively associated with compliance attitude.

H9: Tax voluntary compliance attitude is positively related with awareness on penalty on of taxpayers

H10: voluntary compliance attitude of taxpayers is negatively related to government spending

H11: Organizational efficiency of tax authority is positively correlated with voluntary compliance attitude

H12: Probability of being audit is positively correlated with voluntary compliance attitude of taxpayers

H13: The perception on tax rate is negatively related with tax voluntary compliance attitude

H14: Increase in income level of taxpayers is positively associated with tax voluntary compliance attitude of taxpayers

\section{Review of Related Literature}

Factors that affecting tax voluntary compliance attitude of taxpayers can be divided to five major categories such as (1) [demographic factors like age, gender and education], (2) [individual factors like tax knowledge, personal financial constraints and awareness of offense and penalty], (3) [social variables includes perception on equity and fairness of tax system], (4) [institutional such as simplicity of taxation, role of tax authority, change in government policy and referent group and the probability of being audit] and finally (5) [economic factors consists of tax rate income level, tax audit and perception on government spending [33], [36] and [40].

\subsection{Demographic Factors}

Demographic factors like age, gender and education have long been researched by different authors. With regarding the impact of age on tax compliance attitude findings are difference along the different studies. [58], [62], and [60] postulate negative association between tax compliance attitude and age; older people are less compliant. In contrast, [14] argued that age was positively related with tax compliance attitude of tax payers. However, there have been significant number of studies which found no relationship between age and compliance [43], and [38] also found that older people are more compliant than young people. Concerning the gender of tax payers' study done [25], and [58] found that female taxpayers were more compliant than males. In difference, [47], [8] and [39] suggested that gender has no significant impact on compliance attitude of taxpayers. Foregoing literature supports the direct, positive relationship between educational level and taxpayer compliance attitude' [10], [11], [31], 33], and [39] also suggested that education level is directly linked to a likelihood of compliance attitude. Educated taxpayers are more compliant than uneducated taxpayers.

\subsection{Individual Factors}

Decisions regarding either to evade or not to evade taxes are heavily reliant on taxpayer's personal judgment [38]. Personal circumstantial factors like tax knowledge, personal financial constraints and awareness of penalties and offences are therefore likely to have a significant impact on taxpayers' compliance attitude. The influence of tax knowledge on compliance behavior has been described in various researches. Previous studies have evidenced that tax knowledge has a very close relationship with taxpayers' ability to comply [51], [17], [37] and [44] concluded that tax knowledge have significant impact on tax compliance attitude of the tax payers. Personal financial constraints are believed to have an impact on tax evasion as financial distress faced by an individual and may encourage him to prioritize what has to be paid first as basic survival needs such as (foods, clothing, housing etc.) People who face personal financial problems are likely to be more disposed to evade tax. When compared to people with less financial distress [38]. With regarding to Awareness of offense and penalties a theoretical economic model introduced by studies [5], [6], [20], [21], [22], [23], and [24] has clearly indicated that penalties as well as audit probability have an impact on tax compliance behavior. The higher the penalty and the potential audit probability the greater the discouragement for potential tax evasion. If the taxpayers are aware of the offences they are committing when evading tax and the consequences of being non-compliant taxpayers, they might reduce their tendency to evade tax.

\subsection{Social Factors}

Besides to demographic and individual factors affecting tax compliance attitude of citizen, social life of taxpayers has its own impact on compliance attitude. To this end, [34], stated that the issue of noncompliance is not only a question of state-society relationships but also a question of relationship between citizens or groups of citizens within local communities. There is an existing social bond between the society and this bond influences the members of the society in complying with the tax. These factors are perceptions of equity and fairness, changes to current government policy and referent groups.

Perceptions of equity or fairness: one of the main principles of the taxation system design is equity or fairness, which can be perceived through three dimensional views horizontal equity (people with the same income or wealth brackets should pay the same amount of taxes), vertical equity (taxes paid increase with the amount of the tax base or taxable income) and Exchange Equity 
(expectation the same share of public service from government for paying tax) [61]. The perceived fairness of the tax system also has an influence on the inclination towards tax evasion [29].

With regarding to changes to current government policies as one factor that affect tax compliance attitude of taxpayers, studies have disclosed that the government decisions and changes to policies in accordance with the economic and political situation have a significant impact on compliance. For example, a positive move made by political situation has a significant impact on compliance attitude. For instance, a positive move made by the government such as an increase in tax rebate [25] is likely to increase taxpayers' compliance.

A referent group (peer influence) has its own impact on compliance attitude of taxpayers. [2] In their Theory of Reasoned action [TRA] and Theory of planned Behavior [TPB] hypothesized that referent groups play a significant role in determining people's intentions and behavior regarding tax compliance. Decisions either to evade or not to evade tax sometimes are influenced by family members or friends [5]. Therefore, the influence of referent groups is seemingly important in making a decision, particularly involving monetary aspects and the obedience to laws.

\subsection{Institutional Factors}

The evidence suggests that institutional factors role of the tax authority, simplicity of tax system and probability of detection also play vital role in their compliance decisions [38]. The role of the tax authority in minimizing the tax gap and increasing voluntary compliance is clearly very important. [15] Exemplified that tax compliance is placing the government and the tax authority as the main party that need to be continuously efficient in administering the tax system in order to decrease tax evasion. Besides, the study of [48] also suggested that the role of a government has a significant positive impact on determining attitudes toward tax. Concerning the simplicity of the tax system [8] and [50] discussed the importance of the tax authority having a simple tax return and system from the taxpayers' point of view encourages the taxpayers to comply with tax law. In addition, [50] again added that simplifying the tax return will encourage tax payers to complete the tax return on their own rather than employing a tax agent and thus reducing compliance costs as the main feature of SAS. Probability of detection by audit also plays a significant role in reporting behavior of tax payers. Taxpayers will declare the whole thing if they perceive that they will be one of the taxpayer to be audited in a particular year [45] and [48]. On other hand, [52] investigated the relationship between the probability of being audited and the taxpayers' attitudes recommended that as the probability of detection increased, taxpayers are encouraged to comply with tax laws and accurately report their income.

\subsection{Economic Factors}

The effect of tax rate on tax compliance is mixed. According to [63] raising marginal tax rates will be likely to encourage taxpayers to evade tax more. [41] In their empirical study also find that the increase in tax rate strengthens the incentive to report less income to compensate the reduced income. Another study in [53] used an econometric model to explain the relationship between marginal tax rates and noncompliance by using aggregate data in the United States, demonstrated that tax rates were negatively correlated with tax compliance according to his data. Opposite to the view there are some researchers who found out there is positive relationship between tax compliance and tax rate. For instance, [7] fined a positive relation between the tax compliance and high tax rate. In their experimental research fined respondents to be more compliance when the tax rate was increased. Put differently, [43] in their study find out there is no relationship between tax compliance and tax rate.

In most researches income level is classified as one of demographic factors affecting tax compliance but in current study it classified as economic factor because, income earning capacity of a Person or corporate citizen is depending on economic aspect citizens. Even if [27], [28], [29] and [31] found that income level has a mixed and unclear impact on compliance, but they did not clearly too inconsistent findings. For instance, progressive tax rates might encourage the higher income group to evade rather than the lower income group because of high tax rates which makes their taxable income high, consequently, making the tax liabilities much higher than lower income group. In a country where income redistribution is not satisfactory, the higher income group tends to evade more [38].

According to [38], tax audit could be an important stimulant to increase tax compliance. This indicates that tax audit influence tax compliance. Audits rates and the diligence of the audits could encourage taxpayers to be more prudent in completing their tax returns, report all income and claim the correct deductions to ascertain their tax liability [39). Tax audit increases tax compliance because of deterrent effect of audit on the noncompliance of taxpayers. Some studies by [15], [16] and [28] claimed that tax audits have a positive impact on tax evasions.

Citizens will be sensitive to what the government spends their money on. If the government is wisely spending the national revenue, for example, for basic facilities like education, health and safety and public transportation tax payers feel positive and comply but, if it is spending too much on something considered unnecessary or unbeneficial to them or general public, then taxpayers will feel betrayed and attempt to evade. To this end, [32] stated that taxation is one method of transferring resources from the private to the public sector. The role of taxes as an 
instrument that stabilizes the economy and reduces private demand so that resources can be released for public sector use and generally, governments levy taxes for multiple of purposes, but mainly to raise funds in order to cover public expenditures in one hand and to properly allocate resources on the other hand.

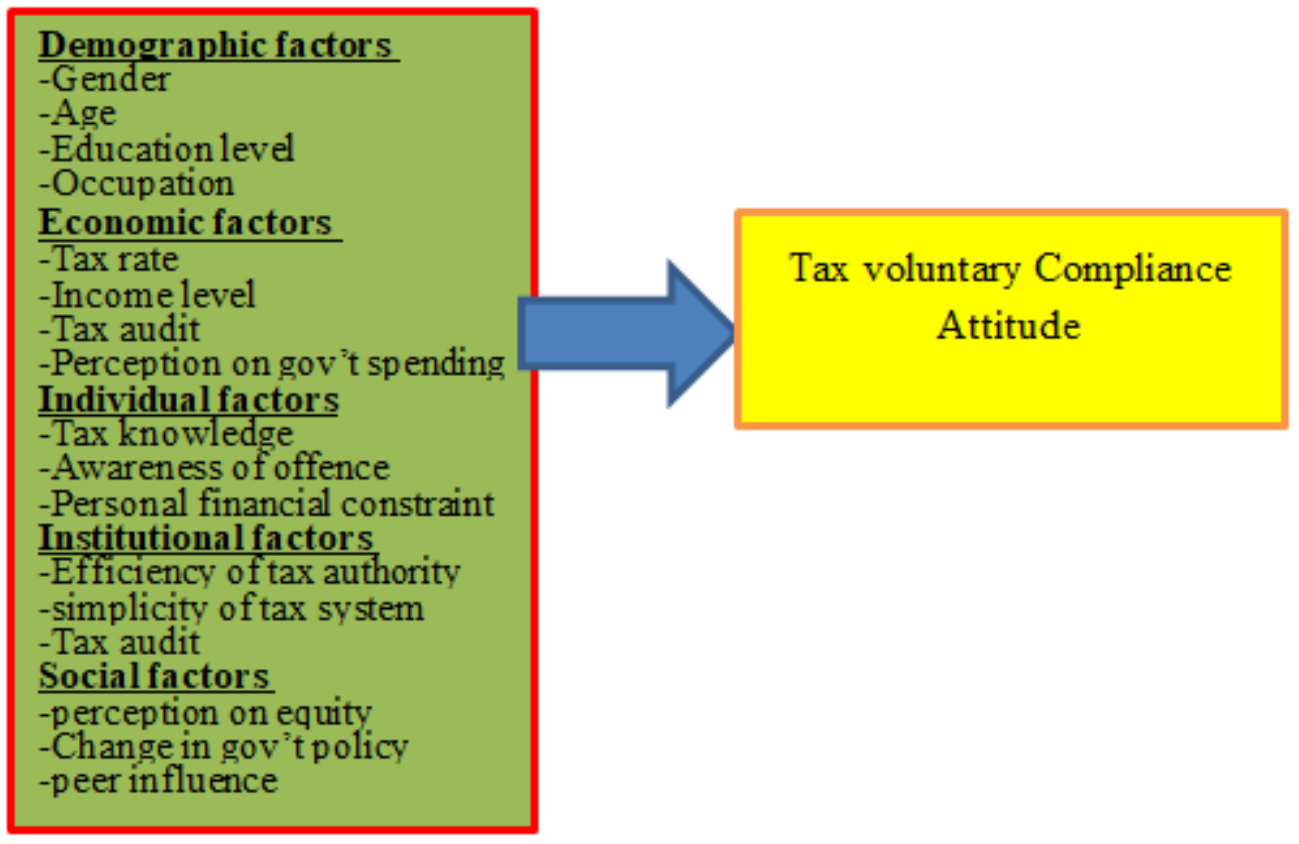

Figure 1. Source: own construct [2018]

\subsection{Conceptual Framework of factors influencing Tax voluntary Compliance Attitude with tax system}

NB: The variable in the rectangle at the right side (tax voluntary compliance attitude) is dependent variable and the other variables such as (economic, social, institutional, individual and demographic factors) that listed in the rectangle at left side are independent variables.

\section{Research Methodology}

\subsection{Research Approach}

In general there are two research approaches. These are quantitative and qualitative research approaches. Quantitative research approach involving numerical or statistical data and emphasis is on the quantifiable observations of the research which is mainly objective. Whereas, qualitative research approach is an approach to gather non-numerical data in which Words and observations are used to express the reality where 'getting close to the data' and an 'in-depth' approach are key concerns. This type of research is mainly subjective [1]. In current study the author employed both approaches to achieve the objective of the research.

\subsection{Data Type and Methods of Data Collection}

In this research, the author used both primary and secondary data. To collect primary data structured questionnaires and direct personal interview were used. The questionnaire was prepared in both Amharic and English languages that helps to reduce language understanding barriers. The questionnaires were adopted and developed with some modification from previous similar studies such as [38]; [39]; [56] used Closed ended questionnaires were prepared in the form of five Likert-Scale, Where; Strongly Agree $[\mathrm{SA}]=5$; Agree $[\mathrm{A}]$ $=4$; Neutral $[\mathrm{N}]=3$, Disagree $[\mathrm{D}]=2$; and Strongly Disagree $[\mathrm{SD}]=1$; for continuous variables. The use of Likert scale is to make it easier for understanding, reduce confusion in reading and answering the questionnaire by respondents. Rational yes or no questions were also developed for dummy variables to be easily answered by taxpayers.

\subsection{Target Population of the Study, Sampling Techniques and Sample Size Determination}

The study population of this research is tax authority and total taxpayers in Gedeo Zone of Southern Ethiopia. According to "[19]" there are three categories of business income taxpayers based on their annual gross income. These are " $\mathrm{A}$ ", " $\mathrm{B}$ " and ' $\mathrm{C}$ ' categories respectively. Categories " $A$ " taxpayers are business entities that have an annual gross income of Birr 1,000,000 (one million Birr thousand Birr) and more. Category "B" taxpayer being a person, other than a Company, having an annual gross income of Birr 500,000 or more but less than $1,000,000$ and category " $\mathrm{C}$ " 
taxpayer being a person other than a Company, having an annual gross income of less than Birr 500,000.

According to Gedeo Zone Revenue Authority report of the year 2016/17 G.C, there were total of 1,678 taxpayers consists of 1,069 category "A", taxpayers 396 category "B", taxpayers and 213 category " $C$ " business income taxpayers in Zone. These have taken as target population of this study by the author. Then, the researcher considered three categories of taxpayers as clusters and selected sample out of each three clusters using simple random sampling because in scenario of selecting sample from clusters "the groups are termed clusters in this form of sampling and can be based on any naturally occurring grouping"'[79].

To determine the sample size from total taxpayers in the Zone, mathematical formula of [64] was used by taking in to account the total population, the sampling error and the level of reliability. It is assumed that the sample would have $95 \%$ reliability about population and a sampling error was $5 \%$. This simplest formula is:

$$
n=\frac{N}{1+(0.05)^{2} * N}
$$

Where $\mathrm{N}=$ study population, $\mathrm{n}=$ sample size and $\mathrm{e}=$ error margin

Accordingly, sample was first determined from total target population by formula of [64] as $323=$ $\frac{1,678}{1+(0.05)^{2} * 1,678}$ then, to randomly select sample from three categories by the following formula of [29] was also used by the author and showed in the following table 1. This is: $n h=(N h / N s) * n$ Where, $n h=$ sample size from each site, $\mathrm{Nh}=$ total population, $\mathrm{Ns}=$ target population and $\mathrm{n}=$ sample size from target population.

Table 1. Determination of sample size from each category by applying formula

\begin{tabular}{|c|c|c|c|}
\hline $\begin{array}{c}\text { Sampling } \\
\text { cluster }\end{array}$ & $\begin{array}{c}\text { Population of } \\
\text { each category }\end{array}$ & $\begin{array}{c}\text { Sample size } \\
\text { Calculations }\end{array}$ & $\begin{array}{c}\text { Sample } \\
\text { size }\end{array}$ \\
\hline $\begin{array}{c}\text { Category } \\
\text { "A" }\end{array}$ & 1,069 & $\begin{array}{c}(1,069 / 1,678) \\
* 323\end{array}$ & 206 \\
\hline $\begin{array}{c}\text { Category } \\
\text { "B" }\end{array}$ & 396 & $(396 / 1,678) * 323$ & 76 \\
\hline $\begin{array}{c}\text { Category } \\
\text { "C" }\end{array}$ & 213 & $(213 / 1,678) * 323$ & 41 \\
\hline Total & 1,678 & $\begin{array}{c}(1,678 / 1,678) \\
* 323\end{array}$ & 323 \\
\hline
\end{tabular}

Source: Personal survey [2016/17]

Therefore, the maximum sample size from all business income taxpayer was 323 taxpayers. The logic behind using probability sampling technique is to give equal chance to the all taxpayers' in all three categories, to select representative sample for the study and to save the resources. Besides, the researcher used purposive sampling technique to select tax officers in the Zone using for interview purpose to obtain relevant information about the topic. This is concept of using probability and non-probability sampling techniques to achieve the objective of this study.

\subsection{Econometric Model Development}

Tax voluntary compliance attitude is discrete random variable and dummy in nature that could be measured through logit or binary logistic regression model. Accordingly, the researcher has developed the model by driving logit function from odds ratio and incorporated fourteen explanatory variables which disclosed as follows: TVCA $=$ F [GED, AGE, EDU, TK, SIM, TAU, PFE, AP, PTR, IL, PGS, PI, OCCP, TAE]. Hence, the researcher has developed the logistic regression model to achieve the objective of this study.

Logistic regression is one of binary choice models (or dichotomous models), which is designed to model the 'choice' between two discrete alternatives. This model essentially describes the likelihood of observing success event $\left(\boldsymbol{Y}_{\boldsymbol{i}}=\mathbf{1}\right)$ is directly depends on observed explanatory variables which are exogenous to the model. Tax compliance attitude issues is the two kinds attitude matter in its nature; tax payers may comply voluntarily (positive compliance attitude) or (negative compliance attitude).Taxpayers are assumed to have positive voluntary compliance attitude if they assess themselves by reporting their correct taxable income to tax authority (at right time, place, correct amount and in appropriate manner) without any legal enforcement and it is their willingness to comply with directives and regulations of authorities. In contrary, taxpayers may have negative voluntary compliance attitude if they are enforced by tax authority on those who are unwilling to pay their taxes at right time, place, correct amount and incorrect manner through the threat and application of audit and fine. Therefore, based on the above theoretical concept, the researcher developed the model. Since, dependent variable, (i.e., tax compliance attitude) is a binary outcome (dichotomous) variable and treated as qualitative data and the researcher assumes one (1) for positive voluntary compliance attitude, otherwise zero (0). For this data, logistic regression is appropriate model to measure how explanatory variables (factors influencing voluntary compliance attitude) affect individual's likelihood of having positive voluntary compliance attitude or negative compliance attitude. Because the binary result variables violate some assumptions of linear regression models such as (heteroskedastic and non-normal). The Logit function can be derived from odds rations:

$$
\begin{gathered}
\log (\text { Oddsratio })=\log \left(\frac{\text { Success }}{\text { Failure }}\right)= \\
=\log \left(\frac{y_{i}=1}{y_{i}=0}\right)=\beta_{0}+x_{i}^{\prime} \beta
\end{gathered}
$$

Where, $\boldsymbol{y}_{\boldsymbol{i}}=\mathbf{1}$ represents an individual " $\mathbf{i}$ " is being compliant attitude (success), $\boldsymbol{y}_{\boldsymbol{i}}=\mathbf{0}$ represents an individual "i" is being non-compliant (failure), $\boldsymbol{x}_{\boldsymbol{i}}$ is column vector of explanatory variables (GEND, AGE, EDUC, TKLDGE, SIM, PFE, TAU, APEN, PTR, and TAE, $\boldsymbol{\beta}$ is column vector of parameters (coefficients) to be estimated and $\boldsymbol{\beta}_{\mathbf{0}}$ is the intercept term. Equation (3.1) 
shows that natural logarithmic form of odds ratio depends on observed explanatory variables.

Equation (6.1) can also be expressed in terms of probability:

$$
\log \left(\frac{P\left(y_{i}=1\right)}{P\left(y_{i}=0\right)}\right)=\log \left(\frac{P\left(y_{i}=1\right)}{1-P\left(y_{i}=1\right)}\right)=\beta_{0}+x_{i}^{\prime} \beta
$$

Where, $\boldsymbol{P}\left(\boldsymbol{y}_{\boldsymbol{i}}=\mathbf{1}\right)$ is the probability of having positive compliance attitude and $\mathbf{1}-\boldsymbol{P}\left(\boldsymbol{y}_{\boldsymbol{i}}=\mathbf{1}\right)$ is the probability of having negative compliance attitude. The stochastic version of equation (3.2) can be formulated by adding disturbance error term:

$$
\log \left(\frac{P\left(y_{i}=1\right)}{1-P\left(y_{i}=1\right)}\right)=\beta_{0}+x_{i}^{\prime} \beta+U_{i}
$$

Where, $\boldsymbol{U}_{\boldsymbol{i}}$ is stochastic error term which represents all unobservable factors of tax compliance, and this model shows that odds ratios is not only depends on variables incorporated in the model but also other factors which are not included in the equation. By taking exponential (antilogarithm) both side of equation [(3.3] and rearranging it we have logistic function as follows:

$$
\frac{P\left(y_{i}=1\right)}{1-P\left(y_{i}=1\right)}=\exp ^{\left(\beta_{0}+x_{i}^{\prime} \beta+U_{i}\right)}
$$

$$
\begin{gathered}
P\left(y_{i}=1\right)=\left(1-P\left(y_{i}=1\right)\right) \exp ^{\left(\beta_{0}+x_{i}^{\prime} \beta+U_{i}\right)} \\
P\left(y_{i}=1\right)=\frac{\exp \left(\beta_{0}+x_{i}^{\prime} \beta+U_{i}\right)}{1+\exp \left(\beta_{0}+x_{i}^{\prime} \beta+U_{i}\right)}
\end{gathered}
$$

Equation [3.4] describes that the probability of being positive compliant attitude depends on observed exogenous variables. This probability is positive and limited between 0 and 1 because the underlying model follows logistic distribution. The predicted probability of positive tax compliance attitude therefore can be expressed as:

$$
\widehat{\boldsymbol{P}}\left(y_{i}=\mathbf{1}\right)=\frac{\exp \left(\widehat{\boldsymbol{\beta}}_{0}+x_{i}^{\prime} \widehat{\boldsymbol{\beta}}\right)}{1+\exp \left(\widehat{\boldsymbol{\beta}}_{0}+x_{i}^{\prime} \widehat{\beta}\right)}
$$

\subsection{Description of Variables and their Scale of Measurement}

From the theoretical and empirical literature, traditional

\begin{tabular}{|c|c|c|c|}
\hline Variables & Symbol & Unit of measurement & Expected sign \\
\hline \multicolumn{4}{|c|}{ Dependent variable } \\
\hline Tax voluntary compliance attitude & TVCA & Dummy & \\
\hline \multicolumn{4}{|c|}{ Explanatory variables } \\
\hline Gender of respondent & GED & Nominal & + \\
\hline Age of respondent & AGE & Ordinal & + \\
\hline Education status of tax payers & EDU & Ordinal & + \\
\hline Probability of being audit & TAU & Continuous & + \\
\hline Peer influence & PI & Ordinal & - \\
\hline Occupation & $\mathrm{OCCP}$ & Dummy & + \\
\hline Perception on government spending & PGS & Continuous & - \\
\hline Income level of taxpayers & IL & Continuous & + \\
\hline Perception Simplicity of tax system & SIM & Continuous & + \\
\hline Perception on fairness and equity of tax system & PFE & Continuous & + \\
\hline Organizational efficiency of tax authority & TAE & Nominal & + \\
\hline Tax knowledge of tax payers & TK & Nominal & + \\
\hline Perception on tax rate structure & PTR & Nominal & - \\
\hline Awareness on Penalty for tax evasion & AP & Continuous & + \\
\hline
\end{tabular}
observable characteristics that may influence the probability of having voluntary compliance attitude of tax payers were summarized with their respective unit of measurement in table 2 below.

Table 2. Variables and their description

+, Positive effect; -, Negative effect.

Source: Own construct (2018) 


\subsection{Tools of Data Analysis}

After accomplishment of data collection procedure, it should have classified as per each variable, the qualitative data was coded to be measured quantitatively. In this research data were analyzed by the help of Stata Software package version 12.0 and SPSS version 23.0 in order to get the reliable finding.

\subsection{Ethical Consideration}

The following ethical considerations have been given attention by the researcher and enumerators while conducting the research that includes voluntary participation, no harm to participants, anonymity and confidentiality, not deceiving the subjects and privacy of participants. Conserving the voluntary participation of respondents, no participants were forced to take part in the research and participants were free to withdraw from the research at any moment. With regarding to harm to participants, the researcher ensured that there is no any physical or psychological harm done to the participants as a result of the study. When it comes to Anonymity and confidentiality, all information gathered during the study has been handled confidentially and permission from the participants was obtained for all information to be shared publicly. Not deceiving the subjects since participants have informed clearly about the aim, purpose and procedures of the study and was not deceived in any way. Finally Privacy of participants the privacy of the participants have been respected.

\section{Results and Discussion}

The total numbers of (323) three hundred twenty three questionnaires were organized and distributed to taxpayers, of which (201) two hundred one questionnaires were filled completely and returned back. This has made the return rate around $62.23 \%$. After the data were collected, checked for errors and completeness. This study employed binary logistic regression for data analysis. Besides, an in-depth interview was also conducted with tax officers and taxpayers' representatives in the study area to know clear findings of this study and to forward conscious recommendations. 


\subsection{Pearson Correlation Matrix for Dependent and Independent Variables analysis through SPSS}

Table 3. Pearson correlation matrix for dependent and independent variables

\begin{tabular}{|c|c|c|c|c|c|c|c|c|c|c|c|c|c|c|c|}
\hline Variable & TVCA & GED & AGE & EDU & TK & PI & OCCP & SIM & PFE & PGS & AP & IL & TAU & PTR & TAE \\
\hline TVCA & 1.000 & & & & & & & & & & & & & & \\
\hline GED & $\begin{array}{c}-0.230 * * \\
\text { Sig } 0.001 \\
\mathrm{~N}=201 \\
\end{array}$ & 1.000 & & & & & & & & & & & & & \\
\hline AGE & $\begin{array}{c}0.231^{* *} \\
\text { Sig } 0.001 \\
\text { N=201 }\end{array}$ & $\begin{array}{c}-0.002 \\
0.978 \\
201 \\
\end{array}$ & 1.000 & & & & & & & & & & & & \\
\hline EDU & $\begin{array}{c}-0.043 \\
\text { Sig } 0.549 \\
\mathrm{~N}=201 \\
\end{array}$ & $\begin{array}{c}0.012 \\
0.868 \\
201 \\
\end{array}$ & $\begin{array}{c}-0.035 \\
0.623 \\
201 \\
\end{array}$ & 1.000 & & & & & & & & & & & \\
\hline TK & $\begin{array}{c}-0.283^{* *} \\
\text { Sig } 0.000 \\
\mathrm{~N}=201\end{array}$ & $\begin{array}{c}0.051 \\
0.475 \\
201 \\
\end{array}$ & $\begin{array}{c}-0.039 \\
0.585 \\
201 \\
\end{array}$ & $\begin{array}{c}0.084 \\
0.237 \\
201 \\
\end{array}$ & 1.000 & & & & & & & & & & \\
\hline PI & $\begin{array}{c}0.002 \\
\text { Sig0.976 } \\
\mathrm{N}=201\end{array}$ & $\begin{array}{c}-0.099 \\
0.236 \\
201\end{array}$ & $\begin{array}{c}0.169^{*} \\
0.042 \\
201\end{array}$ & $\begin{array}{l}-.024 \\
.771 \\
201\end{array}$ & $\begin{array}{c}0.213^{*} \\
0.010 \\
201\end{array}$ & 1.000 & & & & & & & & & \\
\hline OCCP & $\begin{array}{c}0.021 \\
\text { Sig0.770 } \\
\mathrm{N}=201\end{array}$ & $\begin{array}{c}-0.037 \\
0.604 \\
201\end{array}$ & $\begin{array}{c}-0.039 \\
0.587 \\
201\end{array}$ & $\begin{array}{c}0.091 \\
0.201 \\
201\end{array}$ & $\begin{array}{c}0.084 \\
0.235 \\
201\end{array}$ & $\begin{array}{c}0.117 \\
0.160 \\
201\end{array}$ & 1.000 & & & & & & & & \\
\hline SIM & $\begin{array}{c}0.489^{* *} \\
\text { Sig0.000 } \\
\text { N=201 }\end{array}$ & $\begin{array}{c}-0.055 \\
0.435 \\
201\end{array}$ & $\begin{array}{c}0.125 \\
0.076 \\
201\end{array}$ & $\begin{array}{c}0.034 \\
0.628 \\
201\end{array}$ & $\begin{array}{c}-0.112 \\
0.066 \\
201\end{array}$ & $\begin{array}{c}0.016 \\
0.817 \\
201\end{array}$ & $\begin{array}{c}0.167^{*} \\
0.018 \\
201\end{array}$ & 1.000 & & & & & & & \\
\hline PFE & $\begin{array}{c}-0.037 \\
\text { Sig0.598 } \\
\mathrm{N}=201\end{array}$ & $\begin{array}{c}0.066 \\
0.355 \\
201\end{array}$ & $\begin{array}{c}0.145^{*} \\
0.040 \\
201\end{array}$ & $\begin{array}{c}0.020 \\
0.779 \\
201\end{array}$ & $\begin{array}{c}-0.051 \\
0.468 \\
201\end{array}$ & $\begin{array}{c}0.209^{*} \\
0.012 \\
201 \\
\end{array}$ & $\begin{array}{c}0.272^{* *} \\
0.000 \\
201\end{array}$ & $\begin{array}{c}0.065 \\
0.360 \\
201 \\
\end{array}$ & 1.000 & & & & & & \\
\hline PGS & $\begin{array}{c}0.014 \\
\text { Sig0.847 } \\
\text { N=201 } \\
\end{array}$ & $\begin{array}{c}0.058 \\
0.342 \\
201 \\
\end{array}$ & $\begin{array}{c}0.135 \\
0.056 \\
201 \\
\end{array}$ & $\begin{array}{c}0.121 \\
0.011 \\
201 \\
\end{array}$ & $\begin{array}{c}0.111 \\
0.055 \\
201 \\
\end{array}$ & $\begin{array}{c}0.225^{* *} \\
0.001 \\
201 \\
\end{array}$ & $\begin{array}{c}0.101 \\
0.152 \\
201 \\
\end{array}$ & $\begin{array}{c}0.112 \\
0.056 \\
201 \\
\end{array}$ & $\begin{array}{c}0.150 \\
0.119 \\
201 \\
\end{array}$ & 1.000 & & & & & \\
\hline AP & $\begin{array}{c}0.506^{* *} \\
\text { Sig0.000 } \\
\text { N=201 }\end{array}$ & $\begin{array}{c}-0.156^{*} \\
0.027 \\
201\end{array}$ & $\begin{array}{c}0.098 \\
0.164 \\
201\end{array}$ & $\begin{array}{c}0.008 \\
0.890 \\
201\end{array}$ & $\begin{array}{c}-0.190 \\
0.002 \\
201\end{array}$ & $\begin{array}{c}-0.182 * * \\
0.010 \\
201\end{array}$ & $\begin{array}{c}0.135 \\
0.056 \\
201\end{array}$ & $\begin{array}{c}0.344^{* *} \\
0.000 \\
201\end{array}$ & $\begin{array}{c}0.036 \\
0.614 \\
201201\end{array}$ & $\begin{array}{c}0.026 \\
0.719 \\
201\end{array}$ & 1.000 & & & & \\
\hline IL & $\begin{array}{c}0.155^{*} \\
\text { Sig0.028 } \\
\text { N=201 }\end{array}$ & $\begin{array}{c}-0.071 \\
0.315 \\
201\end{array}$ & $\begin{array}{c}-0.002 \\
0.975 \\
201\end{array}$ & $\begin{array}{c}-0.032 \\
0.652 \\
201\end{array}$ & $\begin{array}{c}-0.042 \\
0.652 \\
201\end{array}$ & $\begin{array}{l}-.036 \\
.666 \\
145\end{array}$ & $\begin{array}{c}0.240^{* *} \\
0.001 \\
201\end{array}$ & $\begin{array}{c}0.243^{* *} \\
0.001 \\
201\end{array}$ & $\begin{array}{c}0.297 * * \\
0.000 \\
201 \\
\end{array}$ & $\begin{array}{c}0.110 \\
0.121 \\
201\end{array}$ & $\begin{array}{c}0.110 \\
0.119 \\
201\end{array}$ & 1.000 & & & \\
\hline TAU & $\begin{array}{c}0.508^{* *} \\
\text { Sig0.000 } \\
\text { N=201 }\end{array}$ & $\begin{array}{c}-0.127 \\
0.072 \\
201\end{array}$ & $\begin{array}{c}0.089 \\
0.209 \\
201\end{array}$ & $\begin{array}{c}-0.002 \\
0.981 \\
201\end{array}$ & $\begin{array}{c}-0.176^{*} \\
0.012 \\
201\end{array}$ & $\begin{array}{c}0.090 \\
0.205 \\
201\end{array}$ & $\begin{array}{c}0.270^{* *} \\
0.000 \\
201\end{array}$ & $\begin{array}{c}0.213^{* *} \\
0.002 \\
201\end{array}$ & $\begin{array}{c}0.083 \\
0.241 \\
201\end{array}$ & $\begin{array}{c}0.107 \\
0.010 \\
201\end{array}$ & $\begin{array}{c}0.228^{* *} \\
0.001 \\
201\end{array}$ & $\begin{array}{c}0.181^{*} \\
0.010 \\
201\end{array}$ & 1.000 & & \\
\hline PTR & $\begin{array}{c}0.230^{* *} \\
\text { Sig0.001 }\end{array}$ & $\begin{array}{c}-0.071 \\
0.314\end{array}$ & $\begin{array}{l}0.006 \\
0.916\end{array}$ & $\begin{array}{l}0.052 \\
0.395\end{array}$ & $\begin{array}{c}-0.170 \\
0.094\end{array}$ & $\begin{array}{l}0.176 \\
0.056 \\
\end{array}$ & $\begin{array}{l}0.195 \\
0.056\end{array}$ & $\begin{array}{l}0.153 \\
0.010\end{array}$ & $\begin{array}{c}-0.097 \\
0.112\end{array}$ & $\begin{array}{c}-0.151^{*} \\
0.032\end{array}$ & $\begin{array}{l}0.081 \\
0.253\end{array}$ & $\begin{array}{c}-0.078 \\
0.270\end{array}$ & $\begin{array}{l}0.041 \\
0.563 \\
\end{array}$ & 1.000 & \\
\hline
\end{tabular}




\begin{tabular}{|c|c|c|c|c|c|c|c|c|c|c|c|c|c|c|c|}
\hline & $\mathrm{N}=201$ & 201 & 201 & 201 & 201 & 201 & 201 & 201 & 201 & 201 & 201 & 201 & 201 & & \\
\hline \multirow{3}{*}{ TAE } & -0.110 & -0.014 & 0.045 & 0.013 & 0.061 & -0.002 & $-0.145^{*}$ & $0.165^{* *}$ & $-0.146^{*}$ & 0.135 & -0.133 & 0.022 & -0.036 & $-0.161 *$ & \multirow{3}{*}{1.000} \\
\hline & Sig0.118 & 0.843 & .528 & 0.855 & 0.387 & 0.976 & 0.040 & 0.006 & 0.038 & 0.056 & 0.060 & 0.757 & 0.616 & 0.022 & \\
\hline & $\mathrm{N}=201$ & 201 & 201 & 201 & 201 & 201 & 201 & 201 & 201 & 201 & 201 & 201 & 201 & 201 & \\
\hline
\end{tabular}

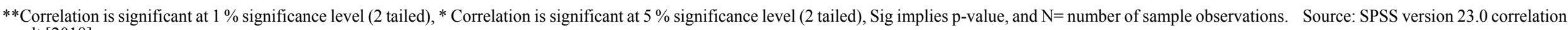
result [2018] 
The result of the study in the above table 3 shows that each variable incorporated in the model has perfectly positively correlated with itself having Pearson correlation coefficient value 1.000. About the relationship between dependent variable (tax compliance attitude [TVCA] and fourteen independent variables, the table 3 displayed that gender of the respondent [GED] being male has significant and negative relationship tax voluntary compliance attitude having Pearson correlation coefficient value of (-0.230) and p-value or sig of 0.001 which is less than 5\% significance level. Accordingly, the age of the respondent [AGE] and voluntary compliance attitude were positively correlated with Pearson correlation coefficient of 0.231 and statistically significant at 5\% level of significance for the reason that p-value or Sig of 0.001 is less than $5 \%$. At the mine time, voluntary Compliance attitude is negatively correlated with lack of tax knowledge [TK] on attending tax education having correlation coefficient of $(-0.283)$ and significant at $99 \%$ confidence interval because p-value 0.000 is less than $1 \%$. Besides, compliance attitude is also positively correlated with the age of the respondent [AGE], simplicity of tax system [SIM], awareness on penalty [AP], income level of taxpayers [IL], probability of being audit [TAU] and perception on existing tax rate [PTR] having Pearson correlation coefficients of $0.231,0.489,0.506,0.155,0.08$, 0.30 and Sig of $0.001,0.000,0.000,0.028,0.000$, and 0.001 respectively were found to be significantly correlated with tax voluntary compliance [TVCA] at $1 \%$ as P-value is less than $1 \%$ except for income level having sig 0.028 which is positively correlated with TVCA at $5 \%$ significance level as $\mathrm{P}$ value of $0.028<0.05]$. while perception of tax authority efficiency was found to be significantly negatively correlated with tax compliance attitude with Pearson correlation coefficient of 0.154 at $5 \%$ significance level because Sig or p-value of $0.011<$ 0.05 .

When it comes to relationship between independent variables incorporated in the model, peer influence is positively correlated with age and tax knowledge with Pearson correlation coefficients of 0.169 and 0.213 at 5\% since p-values of 0.042 and 0.010 that less than 0.05 . Simplicity is also positively correlated with occupation of the respondents with 0.167 Pearson correlation coefficient at $5 \%$ significance level since p-value 0.018 is less than $5 \%$. The perception on fairness of tax system is positively correlated with age, peer influence, occupation having Pearson correlation coefficients of $0.145,0.209$ and 0.272 and statistically significant at $5 \%$ and $1 \%$ because Sig of $0.040,0.012$ is less than $5 \%$ and 0.000 for occupation respectively. Followed by perception on government spending which is positively related with peer influence and simplicity at $1 \%$ level of significance with coefficient of 0.225 (see table 3). Income level of taxpayers is positively correlated with occupation, simplicity, awareness on penalty, perception on fairness and equity having Pearson correlation coefficients of 0.240 , $0.243,0.297$ and statistically significant at $1 \%$ with sig values of $0.001,0.001$ and 0.000 that less than $1 \%$ respectively. In the same way, tax audit (TAU) is positively correlated with other explanatory variables such as occupation, simplicity, awareness on penalty, and income level of taxpayers at $1 \%$ and $5 \%$ levels of significance but negatively correlated with lack of tax knowledge of respondents at 5\% (see table 3 for coefficients and sig values). Next, perception on tax rate is also negatively correlated with perception on government spending having Pearson correlation coefficients -0.151 and significant at $5 \%$ as sig 0.032 less than 0.05 . Finally, tax authority efficiency is negatively correlated with occupation, perception on fairness of equity and perception on tax rate and statistically significant at 5\% but positively correlated with simplicity at $1 \%$ and tax audit at $5 \%$ respectively (see table 3 coefficients and Sig or p-value). In opposite way, the result of Pearson correlation matrix shows that education status, peer influence, occupation, perception on fairness and equity, perception on government spending and tax authority efficiency were not significantly correlated with voluntary compliance attitude of taxpayers (dependent variable) due to fact that their $\mathrm{p}$-values are more than $5 \%$ or $1 \%$ levels of significance respectively. 
Table 4. Regression result: dependent variable (TVCA)

\begin{tabular}{|c|c|c|c|c|}
\hline & & $\begin{array}{l}\text { egression } \\
1 \\
189.67 \\
0.000 \\
.7041 \\
-39.853626\end{array}$ & & \\
\hline Variable & Coef. & Std. Err & $\mathbf{Z}$-value & P-value \\
\hline GED & $-1.406226 * *$ & 0.6759197 & -2.08 & 0.037 \\
\hline AGE & $0.8263969 * *$ & 0.3363375 & 2.46 & 0.014 \\
\hline EDU & 0.1713664 & 0.3348957 & 0.51 & 0.609 \\
\hline TK & $-3.007414 * *$ & 1.038218 & -2.90 & 0.004 \\
\hline PI & -0.2679415 & 0.3720005 & -0.72 & 0.471 \\
\hline OCCP & -0.11749 & 0.6174603 & -0.19 & 0.849 \\
\hline SIM & $1.480397 * * *$ & .4387967 & 3.37 & 0.001 \\
\hline PFE & -0.5901695 & 0.6143349 & -0.96 & 0.337 \\
\hline PGS & -0.4656945 & 0.7346218 & 0.63 & 0.526 \\
\hline $\mathrm{AP}$ & $1.446501 * * *$ & 0.3277764 & 4.41 & 0.000 \\
\hline IL & 0.4286353 & 0.4657414 & 0.92 & 0.357 \\
\hline TAU & $3.146994 * * *$ & 0.6423867 & 4.90 & 0.000 \\
\hline PTR & $2.702777 * * *$ & 0.7252649 & 3.73 & 0.000 \\
\hline TAE & -1.051603 & 0.6289767 & -1.67 & 0.095 \\
\hline CONS & -13.82375 & 4.101089 & -4.38 & 0.000 \\
\hline
\end{tabular}

*** Significant at $1 \%, * *$ Significant at $5 \%$ respectively.

Source: Stata version 12.0 result [2018]

\subsection{Regression Result of Binary Logistic Regression Model}

The result on Table 4 shows that the Pseudo R-square with a value of 0.7041 implies that about 70.41 percent of the changes in tax voluntary compliance attitude [TVCA] could only be explained by explanatory variables namely gender of the respondent [GED], age of the respondent [AGE], tax knowledge [TK], simplicity of tax system [SIM], awareness on penalty rate for evading tax (AP), probability of being audit [TAU], and perception on existing tax rate [PTR]. While 29.59 percent of the changes in tax compliance attitude [TVCA] could be explained by other exogenous factors. The likelihood ratio chi-square of 189.67 with a p-value of 0.000 tells us that the model as a whole is statistically significant.

Consequently, the result of this study shows male tax payers have negative relationship with tax voluntary compliance attitude but positive for female taxpayers $[\beta=$ $-1.406226]$ and statistically significant at $5 \%$ level because, $(p$-value $=0.037)$ is less than $5 \%$ significance level and $Z$ critical value of $(\mathrm{Z}=2.08)$ which more than $1.96 \mathrm{Z}$ table value at 95 confidence level. Hence, hypothesis $\mathrm{H} 1$ is accepted. This result is consistent with finding of other studies results [38], [54] and [8]. This result provides evidence that the probability of having positive voluntary compliance attitude for female taxpayers is more than that of male i.e. women were found to have more compliant than men taxpayers. The taxpayers representatives and tax officers asked why female taxpayers comply more comply tax than male and responded that according to the total culture of Ethiopian, female more respects religious code of conducts, customs of culture, social group believes and different regulations of the country in general than male taxpayers. This finding provides possible recommendation for the tax authority and policy makers to work on encouraging female business income taxpayers since they have more positive voluntary compliance attitude than male business income taxpayers and educate male taxpayers to comply equally as much as possible with female.

With regarding to age of respondents the probability of having positive tax voluntary compliance attitude $[\beta=0.8263969]$ is positive and statistically significant at $5 \%$ level because, (p-value $=0.014$ ) is less than $5 \%$ significance and $Z$ critical value of $(Z=2.46)$ which more than $1.96 \mathrm{Z}$ table value at 95 confidence level. Therefore, hypothesis $\mathrm{H} 2$ is accepted. This finding is consistent with that of [15], [36], [54], and [8], that more aged taxpayers has positive compliance attitude than younger tax payers. This indicates high the age of respondent, more positive compliance attitude and lower the age of the respondents', lower the positive voluntary compliance attitude. As per interview with tax officers of the Zone, aged taxpayers comply more than less aged taxpayers because more aged people learn more thinks about taxation through their passage long life time and experience in business 
environment. The finding provides that the government should educate the young generation about taxation for the reason that they are less compliant old taxpayers. Hence, it is well if the tax authority works on educating fresh generation about taxation and the importance that it gives for them in particular and the society as the whole in general. So that educating taxpayer is the way they can positively understand about taxation and may be best alternative to improve the compliance attitude of younger generation since the majority of business was occupied by them.

Concerning the impact that lack of tax knowledge for not attending tax education $[\beta=-3.007414]$ has negative with voluntary compliance attitude and significant at $5 \%$ level because, $(p$-value $=0.004)$ is less than $5 \%$ significance and $\mathrm{Z}$ critical value of $(\mathrm{Z}=2.90)$ which more than $1.96 \mathrm{Z}$ table value at 95 confidence level. So, the hypothesis $\mathrm{H} 4$ is accepted. The pervious study done by [51], [17], [38], and [44],) have evidenced that tax knowledge has a significant impact on tax compliance attitude even though the level of tax knowledge varies significantly among respondents due to knowledge gap between them. This implies more the taxpayer knowledge about taxation, more the probability of having positive compliance attitude. Thus, providing more tax knowledge to a larger number of tax payers helps to prevent tax evasion and enhance voluntary tax compliance in Self-assessment system. On the other hand, poorer tax knowledge associated with negative attitudes toward taxation and increases the tendency to evading tax. The interviewed taxpayers and tax officers evidenced that taxpayers comply more after they obtain the possible awareness about taxation than before having necessary knowledge about tax system through tax education. It provides the way to keep the same impact and make it sustainable; the awareness creation should go beyond only giving continuous awareness creation to taxpayers. It should be extended to have consultative session with elderly, tax payers' representatives, clan and religious leaders and other individuals that have high respect from society to influence the overall society to have positive compliance attitude by reducing negative attitude towards taxation in general.

The finding of this study with regard to simplicity of the tax system $[\beta=1.480397]$ has positive relationship with voluntary compliance attitude and more statistically significant next to tax audit and awareness on penalty at $1 \%$ level because, $(p$-value $=0.001$ ) is less than $1 \%$ significance and $\mathrm{Z}$ critical value of $(\mathrm{Z}=3.37)$ which more than $2.567 \mathrm{Z}$ table value at 99 confidence level. Thus, hypothesis $\mathrm{H} 7$ is accepted. This result is consistent with studies such as [50], [8], and [41]. The word 'simple' carries numerous interpretations; at least the majority of taxpayers require that the tax return should be as simple as much as possible. The tax authority may assume as tax return is simple and easy to complete but it may not equally simple for all taxpayers. This indicates that simplifying the tax return will encourage tax payers to complete the tax return on their own rather than employing a tax agent and thus reducing compliance costs as the main feature of self-assessment. Therefore, simplifying tax returns and administration system is the best way to ensure tax compliance. Because taxpayers should not spend much time in ascertaining the accuracy of the returns and calculating their tax liabilities if it is simple and it can facilitate efficient and enhanced administration and reduce compliance costs. The tax officers and taxpayers' representatives interviewed on the issue of simplicity of taxation and responded that current taxation in Ethiopia is simple and easy to understand and this way simplicity of tax system is positively associated with compliance attitude. In the current study the researcher recommended that that, even if the current study shows positive relationship between simplicity and tax compliance attitude, it is better if the tax authority again makes tax system simple as much as possible in general, the forms, the law, the filling, appeal system and paying procedure in particular to increase positive tax compliance attitude of taxpayers better than the current state in order enhance positive compliance attitude in one hand and boost tax revenue in general.

With on the subject of the awareness of penalty for evading tax $[B=1.691497]$ has positive association with compliance attitude and significant at $1 \%$ level because, $(p$-value $=0.000)$ is less than $1 \%$ significance and $Z$ critical value of $(\mathrm{Z}=3.53)$ which more than $2.567 \mathrm{Z}$ table value at 99 confidence interval. Thus, the hypothesis H9 is accepted. This result is also consistent with studies of [5] and [8]. This indicate that higher the penalty the greater the discouragement for potential tax evasion. If the taxpayers are aware of the offences they are committing when evading tax and the consequences of being non-compliant taxpayers. The author made face to face interview with taxpayers' representatives and they responded that more than all other things taxpayers comply tax laws and payer their tax obligations at right time and place for the reason the fear penalty from tax authority for participating in tax evasion. Additionally, it is better to keep the penalty for evading tax as current status and increase awareness of tax payers regarding consequence of take part in tax crimes.

With regarding to the probability of being audit $[\beta=$ 3.146994] has positive relationship with voluntary compliance attitude and most significant at $1 \%$ level because, $(p$-value $=0.000)$ is less than $1 \%$ significance and $\mathrm{Z}$ critical value of $(\mathrm{Z}=4.90)$ which more than $2.567 \mathrm{Z}$ table value at 99 confidence interval. As a result hypothesis $\mathrm{H} 12$ is accepted. This result is consistent with that of [54], and [56]. This finding suggests that more the probability of being caught by tax audit, more positive the taxpayers' voluntary compliance attitude of respondents. This implies that taxpayers comply with taxation for the reason that they fear may caught by tax audit. This supplement by asking the taxpayers why they comply more the tax law due to 
presence of probability of being audit by tax auditors at the end of each year and they responded that they obey tax rule duet fact that they will be punished if they omit any wrong action in preparing tax returns. The author forwarded that tax authority can expand more consistent and regular auditing activities still keeping in mind the cost associated with it minimum and increase tax revenue to the planned one.

At the same time the perception on tax rate $[\beta=$ 2.702777] has positive association with voluntary compliance attitude and significant at $1 \%$ level because, $(\mathrm{p}$-value $=0.000)$ is less than $1 \%$ significance and $\mathrm{Z}$ critical value of $(\mathrm{Z}=3.73)$ which more than $2.567 \mathrm{Z}$ table value at 99 level of confidence. Hence, the hypothesis H13 is rejected. This result similar with that of [7] which suggests that of raising marginal tax rates will be likely to encourage taxpayers to comply with taxation. In opposite studies such as [41] and [53] find out that increase in tax rate strengthens the incentive to report less income to compensate the reduced income. In Ethiopian from years 2004 up to 2018 the corporate, personal income and sale tax (VAT) tax rates were $30 \%, 35 \%$ and $15 \%$ respectively. The researcher has interviewed both tax authority and taxpayers representatives about why tax voluntary compliance attitude is positively associated with perception on tax rate and obtained an idea that says "even though the tax rates remains constant between the years, Ethiopian government has revised the income tax proclamation from proclamation number 286/2002 to proclamation number 979/2016. By keeping tax rates constant income exempted from tax was improved from 0ETB up to $1,800 \mathrm{ETB}$ in first proclamation to $0 \mathrm{ETB}$ up to 7,200 ETB in the 2nd proclamation with difference of 5,400 ETB which was saved for business income taxpayers According to tax officers the reason of changing tax proclamation is to encourage the taxpayers to make correct amount of payments at the right time and comply with taxation and in the same way taxpayers has positive attitude on currently existing tax rate in the country. Consequently, this why perception on tax rate has positive association with compliance attitude and finally, the researcher recommended authority should keep in essence make the tax rate as stable as much as possible without overstating current tax rate. Because the result of this study showed that perception on existing tax rate structure is positively related tax compliance attitude and any tax charges more than current will borne negative perception on tax rate in particular and increase the tax evasion in general.

Finally, tax officers were asked by the researcher about which category of taxpayers comply more out of three categories? Accordingly, they responded that in comparison to category "C" categories "A \& B" taxpayers were relatively pay their tax obligations with in the scheduled time of tax collection by presenting the books of accounts to tax authority offices. The author also asked why categories " $\mathrm{A}$ " and " $\mathrm{B}$ " taxpayers obey tax laws than category ' $\mathrm{C}$ ?' it was responded as categories A \& B taxpayers more comply tax laws because they required to submit their balance sheets and income statements by keeping record to financial accounting standards but it not mandatory for category ' $\mathrm{C}$ ' to keep the record of all business activities and submitting profit or loss account and statement of financial position to tax authority office at the end of tax year.

\section{Conclusions}

According to Pearson correlation Matrix result [see Table 3 ] out of fourteen variables incorporated in the model, eight variables such as gender of taxpayers, age, lack of tax knowledge, simplicity of the tax system, awareness on penalty for evading tax, income level, tax audit and perception on tax rate were significantly correlated with tax voluntary compliance attitude. Results of the Binary logistic regression analysis [see Table 4] also suggested that voluntary compliance attitude is significantly influenced by gender of taxpayers, age, lack of tax knowledge, and simplicity of the tax system, awareness on penalty for evading tax, tax audit, and perception on tax rate. This study similarly evidenced that, other variables such as education level and role and efficiency of tax authority were not significant determinants of tax compliance attitude.

\section{Direction for Further Research}

Any study cannot be necessarily free from limitations to some extent. Accordingly, there are some limitations in present study. At first, it focused only on factors influencing tax voluntary compliance attitude of taxpayers in Gedeo Zone of southern Ethiopia. Thus, the findings of this study can be generalized for all taxpayers in Gedeo Zone but it may be difficult to generalize this findings about all taxpayers at others Zones in SNNPR, and national level. Hence, this study can be improved if it will be done at regional and national level by comparing tax compliance attitude of taxpayers in different business sectors. Further researchers can also include other tax voluntary compliance attitude determinants that were not addressed in this study since current study only tested fourteen factors.

\section{REFERENCES}

[1] Abiy Zegey, Alemayhu Worku, Daniel Tefera, Melese Getu, Yilma Sileshi, 2009. Introduction to Research Methods. 1st ed. Addis Ababa: Addis Ababa University.

[2] Ajzen, I., and Fishbein, M., 1980. Understanding Attitudes 
and Predicting Social behavior. Englewood Cliffs, New Jersey: Prentice Hall.

[3] Alabede, J.O., Ariffin, Z.Z. \& Idris, M., 2011. Tax service quality and compliance behavior in Nigeria: Do taxpayer's financial condition and risk preference play any moderating role?

[4] Alm, J., G. H. McClelland \& W. D. Schulze 1992. Why do people pay taxes? Journal of Public Economics,4 (8), 21-38.

[5] Allingham, M. G., \& Sandmo, A., 1972. Income tax evasion: A theoretical analysis. And Society Review. Volume 25, p. $637-683$.

[6] Allingham, M. G. \&. A. S., 1972. Income tax evasion: a theoretical analysis.. Journal of Public Economics, p. 323 338 .

[7] Alm, J. 1995. A perspective on the experimental analysis of taxpayer reporting. The Accounting Review, pp. 577-593.

[8] Amina and Sniy, 2015. tax compliance and its determinant the case of Jimma zone. International Journal of Research in Social Science, 6(2) pp., 7-21

[9] Belay Zewude Ayele, 2015. Determinants of Tax Revenue Performance: Ethiopian Federal Government, A Thesis is Submitted to the department of Accounting and Finance of Addis Ababa University in Partial Fulfillments of the Requirements for the Degree of Master of Science in Accounting and Finance

[10] , Bhatia, H.L., 1976. Public Finance. 19th edition ed. New Delhi: Vikas Publishing House PvtLtd.

[11] Chan, C.W., Troutman, C.T., and O'Bryan, D., 2000. An expanded model of taxpayer compliance: Empirical evidence from United States and Hong Kong., Auditing and Taxation. Journal of International Accounting, p. 83-103.

[12] Das-Gupta, A., and Chattopadhyay, S., 2002. The Personal Income Tax in India: Compliance Costs and Compliance Behavior of Taxpayerse, National Institute of Public Finance and Policy.

[13] Desta K., 2010. “Assessment of taxpayers' voluntary compliance with taxation: a case of mekelle city, tigray, ethiopia"' MBA, Thesis, MU.

[14] Dubin, J. A., Graetz, M. A., \& Wilde, L. L., 1987. Are we a nation of tax cheater? New econometric evidence on tax compliance. American Economic Review, pp. 240-245.

[15] Dubbin, J.A. (2004).Criminal investigation enforcement activities and taxpayer non- compliance. Paper presented at 2004 IRS Research Conference, Washington.

[16] Eriksen, K and Fallan, L., 1996. Tax knowledge and attitude towards taxation'. Journal of economic psychology, Volume 17, pp. 387- 402

[17] Ermias Ersodo. , 2014. The impact of tax awareness on tax compliance :( The case of Durame town) MA, Thesis, ECSU, Addis Ababa; Ethiopia. Unpublished material available in the library of ECSU

[18] FDRE, National Planning Commission, 2016, Growth and Transformation Plan II (GTP II) (2015/16-2019/20), Volume I: Main Text, Addis Ababa, Ethiopia
[19] FDRE, 2016. "Income Tax Regulation No.979/2016", Federal Negarit Gazeta, Addis Ababa, Ethiopia.

[20] Fjeldstad O.H, H. C. a. S. I., 2012. 'Peoples' View of Taxation in Africa, Research on determinants of tax compliance', International Centre for Tax and Development (ICTD), CHR-michelsen Institution. s.1.:s.n.

[21] Fjeldstad, O. - H. \& J. Semboja, 2001. Why people pay taxes: The case of the development levy in Tanzania. World Development, p. 2059 - 2074.

[22] Franzoni, L., 2000. Tax evasion and tax compliance. Encyclopedia of Law and Economic, Volume VI. In Boukaertm B., De Geest, G. (Eds.), the Economic and Public Tax Law. Cheltenham: Edward Elgar.. Journal of Economics and Sustainable Development.

[23] Gebrie, W., 2006. Tax Accounting in Ethiopian Context. 1st Edition ed. Addis Ababa: Addis Ababa University College of Commerce.

[24] [Giulia Mascagni, Mick Moore, Rhiannon Mccluskey, 2014. Tax Revenue Mobilistation In Developing Countries: Issues And Challenges.

[25] Hasseldine, J., and Hite, P., 2003. Framing, gender and tax compliance. Journal of Economic Psychology, Volume 24, pp. 517-533.

[26] Hasseldine, J., and Li, Z., 1999. More tax evasion research required in new millennium. Crime, Law and Social Change. Volume 31.

[27] Hite, P., 1997. Identifying and mitigating taxpayer compliance. Australian Tax Forum. Volume 13, pp. 155-180.

[28] IMF, 2015. The Democratic Republic of Ethiopia. Press Release. Country Report

[29] Israel G. 1992. Sampling the evidence of extension program impact, Program evaluation and organizational Development', Institution of Food and Agricultural science (IFAS).

[30] Jackson, B., and Jaouen, 1989. Influencing taxpayer compliance through sanction threat or appeals to conscience. Advances in Taxation. Volume 2, pp. 131-147.

[31] Jackson. B.R., and Milliron, V.C., 1986. Tax compliance research: Findings, problems, and prospects. Journal of Accounting Literature. Volume 5, pp. 125-165.

[32] James, S., \& Alley, C., 2002. Tax compliance, self-assessment and tax administration. Journal of Finance and Management in Public Services. Journal of Finance and Management in Public Services, pp. 323-338.

[33] Kirchler, E. Cambridge, 2007. The Economic Psychology of Tax Behavior.

[34] Lemessa, B., 2005. Federal Income Tax Administration in Ethiopia: the case of Employment and Business Income taxes, Msc. Thesis, AAU.

[35] Lemessa,T. , 2007. Determinants of Taxpayers' Voluntary Compliance with Taxation: the case study of Dire Dawa City.

[36] Loo, E.C., 2006. The influence of the introduction on 
self-assessment on compliance behavior of individual taxpayers in Malaysia. PhD thesis. University of Sydney.

[37] Mesfin, B., 2016. Factors influencing tax payers' voluntary compliance with taxation case of Gamo gofa Zone category $A$ and $B$ business income tax payers, MBA. Thesis, DU, Unpublished material available in the library of DU

[38] Mohani, A., 2001. Personal income tax non-compliance in Malaysia. PhD thesis. Victoria University: Melbourne, Australia.

[39] Niway Ayalew Wondwossen, 2016. Determinants of voluntary compliance behaivor evedence from SNNPR, Ethiopia. International Journal of Scince and Research, 5(12), pp. 967-973.

[40] Palil, M. R., 2010. Tax Knowledge and Tax Compliance Determinants in Self-Assessment System in Malaysia. A thesis submitted to The University of Birmingham for the degree of Doctor of Philosophy. Birmingham: The University of Birmingham

[41] Park, C., and Hyun, J.K., 2003. Examining the determinants of tax compliance by experimental data: A case of Korea.. Journal of Policy Modelling, pp. 673-684.

[42] Pelle Ahlerup, Thushyanthan Baskaran \& Arne Bigsten, 2015. Tax Innovations and Public Revenues in Sub-Saharan Africa, The Journal of Development Studies, 2015 Vol. 51, No. 6, 689-706

[43] Praeger. Torgler, B., 2007. Tax Compliance and Tax Morale: A Theoretical and Empirical Analysis.

[44] Redae B. and Pr. Shetlander S, 2016. Redae B. and Pr. Shetlander S. International Journal of Management and Commerce Innovations, 3(2), pp. 1090-1102.

[45] Riahi-Belkaoui, A, 2004. Relationship between tax compliance internationally and selected determinants of tax morale..Journal of International Accounting, Auditing and Taxation, pp. 135-143.

[46] Richardson, G., 2006. Determinants of tax evasion: A cross-country investigation. Journal of International Accounting, Auditing and Taxation, 15(2), pp. 150-169.

[47] , Richardson, G, 2006. The impact of tax fairness dimensions on tax compliance behaviour in an Asian jurisdiction: The case of Hong Kong. Winter. International Tax Journal, pp. 29- 42.

[48] Richardson, G., 2008. The relationship between culture and tax evasion across countries: Additional evidence and extensions. Journal of International Accounting, Auditing and Taxation, , Volume 17, pp. 67-78.

[49] Saunders M. Plewis P. Thorhill A, 2009. Research methods for Business Students. 5th edition ed. FT Prentice Hall: Mark Saunders, Philip Lewis and Adrian Thornhill 2009.

[50] Silvani, C., and Baer, K., 1997. Designing a Tax Administration Reform Strategy: Experiences and
Guidelines. International Monetary Funds.

[51] Singh, V., and Bhupalan, R., 2001. The Malaysian self-assessment system of taxation: Issues and challenges. Tax Nasional, 3rd quarter. pp. 12-17.

[52] Slemrod, J., Blumenthal, M., and Christian, C., 2001. Taxpayer response to an increased probability of audit: evidence from a control experiment in Minnesota, Journal of Public Economics. Volume 79, pp. 455-483.

[53] Tanzi, V., 1980. Inflationary expectations, economic activity, taxes, and interest rates. The American Economic Review, Volume 70(1), pp. 12-21.

[54] Tadesse, G.E, and Goitom A. B, 2014. Factors Influencing taxpayers' compliance with the tax system: An empirical study in Mekelle City, Ethiopia, eJournal of Tax Research (12)2, pp. 433-452

[55] Tesfaye Alemayehu, 2015. Determinants tax revenue in Ethiopia: MSC Thesis for partial fulfillment of the requirement of Masters of Science in Accounting and Finance. AAU; Ethiopia

[56] Tilahun A. \& Yidersal D, 2014. Determinants of Tax Compliance Behavior in Ethiopia: The Case of Bahir Dar City Taxpayers. Journal of Economics and Sustainable Development Volume Vol.5, issue number 15 .pp.268- 273.

[57] Tilly, C. 1992. Coercion, capital and European states: AD 990 - 1992, Malden, Massachusetts: Blackwell Publishers Inc.

[58] Tittle, C., 1980. Sanctions and Social Deviance: The Questions of Deterrence. Connecticutt: Praeger.

[59] Torgler, B. Cheltenham, 2007. Tax Compliance and Tax Morale: A Theoretical and Empirical Analysis.

[60] Wahlund, R., 1992. Tax changes and economic behavior: The case of tax evasion. Journal of Economic Psychology, Volume 13, pp. 657-677.

[61] Wallschutzy, I.G., 1984. Possible causes of tax evasion. Journal of Economic Psychology, pp. 371-384.

[62] Wärneryd, K.E., and Walerud, B., 1982. Taxes and economic behaviour: Some interview data on tax evasion in Sweden. Journal of Economic Psychology, pp. 2,187-2,211.

[63] Whitte A, Woodbury D (1985). The Effect of Tax Laws and Tax Administration on Tax Compliance: The Case of the U.S. Individual Income Tax. Natl. Tax J. retrieved in March 31,2011 frowww.asb.unsw.edu.au/schools/Pages/MargaretMcKerc har.aspx

[64] Yamane, T., 1967. Statistics: An Introductory Analysis. 2nd edition.

[65] Yonas Sandeba, 2016. Tax payers' attitude towards taxation in Gedeo Zone. International Journal of Commerce and Management Research, 2(3), pp. 129-135 